\title{
A Performance Comparison of Anaerobic and an Integrated Anaerobic-Aerobic Biological Reactor System for the Effective Treatment of Textile Wastewater
}

\author{
Tasneem M. Kathawala $\mathbb{D}^{1},{ }^{1}$ K. Veena Gayathri $\mathbb{D}^{\mathbb{D}},{ }^{1}$ and P. Senthil Kumar $\mathbb{D}^{2}$ \\ ${ }^{1}$ Department of Biotechnology, Stella Maris College, Chennai, India \\ ${ }^{2}$ Department of Chemical Engineering, Sri Sivasubramaniya Nadar College of Engineering, Chennai 603110, India \\ Correspondence should be addressed to K. Veena Gayathri; veenagayathri@stellamariscollege.edu.in and P. Senthil Kumar; \\ senthilkumarp@ssn.edu.in
}

Received 25 September 2020; Accepted 25 January 2021; Published 10 February 2021

Academic Editor: Vikranth Kumar Surasani

Copyright (C) 2021 Tasneem M. Kathawala et al. This is an open access article distributed under the Creative Commons Attribution License, which permits unrestricted use, distribution, and reproduction in any medium, provided the original work is properly cited.

\begin{abstract}
The accumulation of recalcitrant azo dyes from untreated textile effluents has adversely impacted the ecosystem. The immense stability in their nature is conferred by the presence of azo bonds $(\mathrm{N}=\mathrm{N})$ in their structure. The reduction of this azo bond occurs exclusively under anaerobic conditions giving rise to colorless aromatic amines, which are carcinogenic. In the present study, a synthetic textile effluent containing mixed azo dyes such as Reactive Red, Reactive Black, and Reactive Brown, was treated using activated sludge under anaerobic conditions in a lab-scale anaerobic sequential batch reactor (An-SBR). At a concentration of $100 \mathrm{mg} / \mathrm{L}$ of mixed azo dyes, the An-SBR gave a maximum of $88 \%$ decolorization detected through UV-visible spectroscopy. Physicochemical analyses revealed $73 \%$ removal of BOD, $90 \%$ TDS removal, 69\% COD removal, 4.05\% TKN removal, 66\% chloride removal, and 73\% hardness removal. When the concentration of dyes was increased to $500 \mathrm{mg} / \mathrm{L}$, the treatment showed a decrease in decolorization efficiency. This was then compared to a sequential anaerobic-aerobic treatment process performed in An-SBR and a laboratory-scale aerobic moving bed biofilm reactor (MBBR). The study revealed that the sequential process held more potential for commercial application than exclusively an anaerobic process. The metabolites formed during the treatment phase were extracted and analyzed by FT-IR and HPLC and identified through GC-MS analyses and were compared to those found in the untreated effluent. A phytotoxicity test was conducted on the remainder (secondary) sludge using Vigna unguiculata, and it was found to show a 50\% reduction in germination and retardation in root and shoot length.
\end{abstract}

\section{Introduction}

The textile industry is one of the world's largest industries and the second largest employment generating industry in India [1]. Several diverse processes occur in the textile industries, and one of the most important among them is the dyeing process. Dyeing is applying color to fabric using dyes, and it is a process that consumes vast quantities of water [2]. Approximately $200 \mathrm{~L}$ of water is consumed to produce $1 \mathrm{~kg}$ of textiles [3]. The residual dyes (10-15\%) significantly affect the penetration of sunlight thereby affecting the natural water body [4].

Azo dyes, characterized by the presence of $-\mathrm{N}=\mathrm{N}$ - (the chromophore), represent the largest class of synthetic dyes to be used for dyeing [5]. The average annual industrial utilization of azo dyes is known to be $7 \times 105$ metric tons [6]. Their annual discharge into the environment via effluents is approximately 50,000 tons [7].

The dye-containing effluents have the most severe consequences upon the aquatic environments into which they are discarded. The presence of varying amounts of dyes imparts a dark color to the water body, blocking sunlight, and the high nitrogen and organic content lead to eutrophication. This leads to a disruption of the aquatic ecosystem $[8,9]$. Another problem occurs during the partial degradation of azo dyes in water bodies. Although the dye is extremely stable under natural conditions, spontaneous reduction of the azo bond under anaerobic conditions or 
photocatalytic degradation may occur, leading to highly carcinogenic and mutagenic colorless aromatic amines [10].

Various treatment methods have been proposed for the removal of dyes and their associated metabolites from textile effluents. These methods include physical techniques like adsorption [11], coagulation, electrocoagulation [12], precipitation, filtration, chemical methods like oxidation (Fenton's oxidation), ozonation, ion exchange, and biological methods. The use of enzymes to remove pollutants has also gained importance owing to their specificity and low toxicity [6]. Among the available methods, biological methods are the simplest, natural, efficient, and inexpensive to perform. Large quantities of effluents can be treated without extreme environmental damage $[9,13]$.

A wide variety of biological methods have been in use to treat textile effluents containing azo dyes effectively. The use of bioreactors has shown several advantages over physical, chemical, and other biological methods. Numerous bioreactors are available, which can be operated in anaerobic [14], anoxic, and aerobic [15] conditions using an activated sludge process and microaerophilic modes. Different reactors can be designed for specific treatment purposes, and two or more bioreactors may be integrated for efficient treatment of industrial effluents $[5,16,17]$.

For the present study, a laboratory-scale anaerobic sequential batch reactor (An-SBR) and an aerobic moving bed biofilm reactor (MBBR) were designed to treat a synthetic textile effluent containing $100 \mathrm{mg} / \mathrm{L}$ and $500 \mathrm{mg} / \mathrm{L}$ of mixed azo dyes-Reactive Red, Reactive Black, and Reactive Brown. The treatment was carried out in two phases: phase I comprised only anaerobic treatment in the An-SBR, and phase II comprised a sequential anaerobic-aerobic treatment involving the An-SBR and the MBBR. The treatments' efficiency was analyzed by monitoring the decolorization, biosorption, and physicochemical parameters (BOD, COD, TDS, TKN, MLSS, MLVSS, hardness, and chloride). The efficacy of this anaerobic treatment was then compared to a sequential anaerobic-aerobic process by comparing the physicochemical tests' outcomes. Furthermore, the metabolites produced posttreatment in both the anaerobic process and the sequential anaerobic-aerobic process were analyzed through FT-IR and high-performance liquid chromatography (HPLC) and identified using gas chromatography mass spectrometry (GC-MS).

The remainder sludge (secondary sludge) generated towards the end of the treatment was tested for its use as a plant fertilizer. A phytotoxicity assay was performed to study the secondary sludge's effects on the germination and growth of cowpea Vigna unguiculata.

\section{Materials and Methods}

2.1. Composition of Synthetic Wastewater. The synthetic textile wastewater was prepared so that its composition would mimic the actual textile effluent. It was prepared by dissolving the following chemicals in $1000 \mathrm{ml}$ of distilled water: potassium dihydrogen phosphate $(500 \mathrm{mg})$, dipotassium hydrogen phosphate $(500 \mathrm{mg})$, ammonium sulfate $(1 \mathrm{~g})$, lactose $(100 \mathrm{mg})$, ferric chloride $(25 \mathrm{mg})$, calcium chloride (1 mg), magnesium sulfate $(10 \mathrm{mg})$, and yeast extract $(25 \mathrm{mg})$. Mixed azo dyes of the required concentration were then added to the prepared and autoclaved synthetic wastewater [18].

2.2. Operational Setup. The synthetic textile effluent treatment was performed in a laboratory-scale anaerobic sequential batch reactor (An-SBR) and anaerobic moving bed biofilm reactor (MBBR). The An-SBR was constructed using acrylic having an inner diameter of $20 \mathrm{~cm}$ and a height of $50 \mathrm{~cm}$. The reactor had a total volume of 15.71 with a working volume of 81 . The An-SBR was provided with an airtight lid to provide an anaerobic environment. An outlet was provided for the collection of gas, which was secured with airtight tubing. Another port was provided in the lid through which the agitator was introduced. The port was appropriately sealed to prevent the exchange of gases. The agitator was fit with a paddle-shaped impeller and was operated at $120 \mathrm{rpm}$ to ensure uniform distribution of nutrients and microbial cells in the reactor space. A sampling port was provided $5 \mathrm{~cm}$ from the bottom of the An-SBR to draw samples and pass the effluent to the MBBR. The port was fit with a ball valve and sealed aseptically.

The aerobic moving bed biofilm reactor (MBBR) had a height of $60 \mathrm{~cm}$ and an internal diameter of $15 \mathrm{~cm}$ and was constructed using acrylic. The MBBR had a total volume of 10.61 with a working volume of 81 . Aeration was provided via a porous air diffuser located at the reactor's bottom. Apart from providing oxygen into the reactor system, the aeration also circumvented the need for an agitator. Sterile air from the diffuser supported the circulation of the carrier media within the MBBR. A sampling port was provided at the bottom of the reactor through which the samples were drawn, and the effluent was collected in a separate collection vessel towards the end of the cycle. The overall setup of the An-SBR and MBBR is diagrammatically represented in Figure 1 .

2.3. Carrier Media for MBBR. The carriers used in the MBBR were Kaldnes K1 media with a filling ratio (Vmedia/ Vreactor) of 20\% [19]. These are cylindrical plastic-based media $10 \mathrm{~mm}$ in diameter and 0.5 to $0.8 \mathrm{~mm}$ in thickness (Figure S1). They have a total surface area of $500 \mathrm{~m}^{2} / \mathrm{m}^{3}$ and a density of $0.123 \mathrm{gr} / \mathrm{ml}$ (Table 1 ). The carriers were washed well in tap water followed by distilled water, after which they were autoclaved at $121^{\circ} \mathrm{C}$ for 15 minutes at $15 \mathrm{lbs}$ pressure. These carriers were used to support biofilm formation in the MBBR. The reactor was initially operated for 40 days with dye-free synthetic wastewater and activated sludge in equal volumes to promote biofilm growth on the carrier surface.

2.4. Operation of the An-SBR and MBBR. A single complete cycle of the An-SBR lasted 96 hours and comprised 5 phases-FILL (30 minutes), REACT (91 hours), SETTLE (2 hours), DECANT (30 minutes), and IDLE (2 hours) (Figure S2). The reactor was filled with $4 \mathrm{~L}$ of synthetic effluent and $4 \mathrm{~L}$ of activated sludge during the FILL phase. 


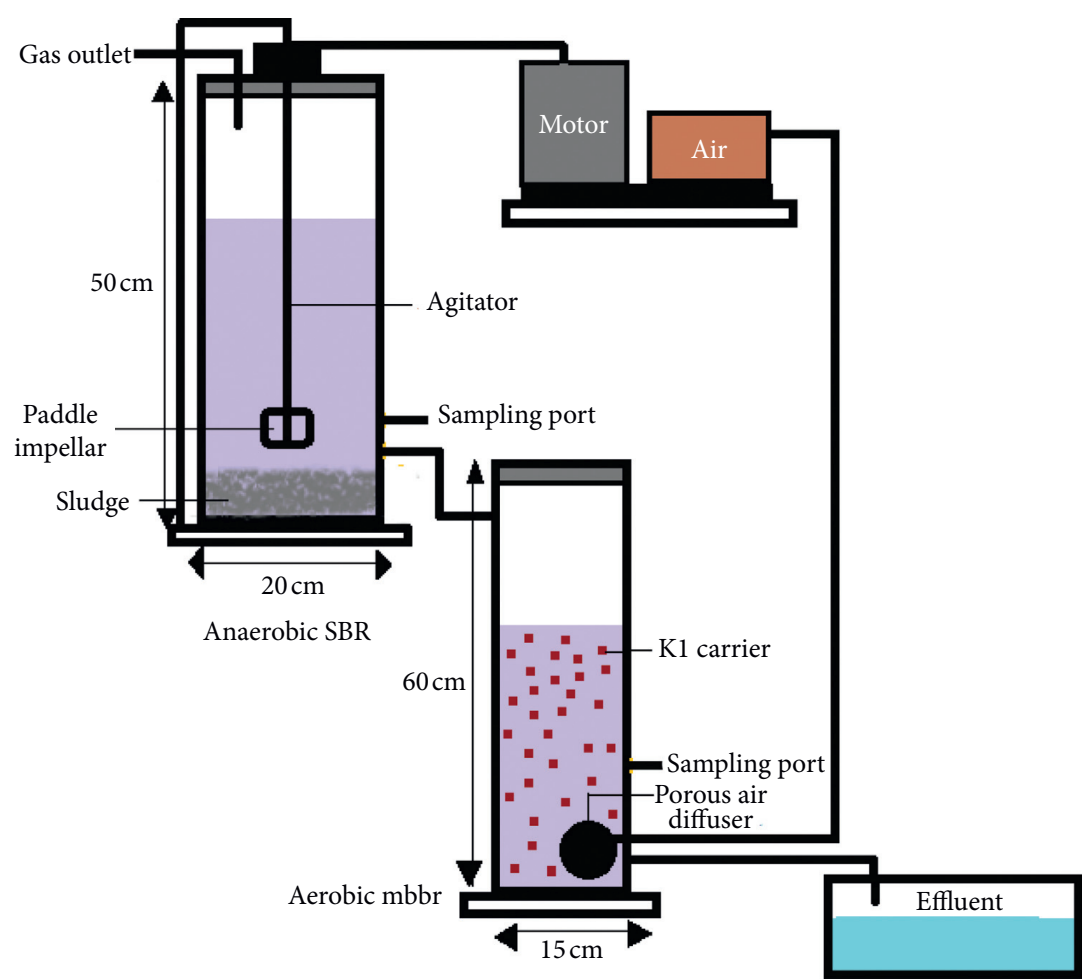

FIgURE 1: Diagrammatic representation of the overall setup of the An-SBR and MBBR.

TABLe 1: Specification of Kaldnes K1 media [19].

\begin{tabular}{lc}
\hline Specification & Value \\
\hline Material & Plastic (PE) \\
Diameter & $10 \mathrm{~mm}$ \\
Thickness & $0.5-0.8 \mathrm{~mm}$ \\
Shape & Cylinder \\
Density & $0.123 \mathrm{gr} / \mathrm{ml}$ \\
Surface area & $500 \mathrm{~m}^{2} / \mathrm{m}^{3}$ \\
\hline
\end{tabular}

The total hydraulic retention time (HRT) for the exclusively anaerobic phase was 91 hours, and this was reduced to 45 hours in the sequential anaerobic-aerobic treatment cycle. Samples were drawn from the sampling port every 24 hours during the DECANT phase, and on the final day of the cycle, the effluent was utterly drained, and the fresh synthetic effluent was added after the IDLE phase.

The An-SBR was operated for 60 days with two different concentrations of mixed azo dyes: 100 and $500 \mathrm{mg} / \mathrm{L}$, and all operations were carried out at room temperature. The reactor was initially operated for 15 days with equal volumes of synthetic textile effluent (without azo dyes) and activated sludge to facilitate the sludge's acclimatization to the reactor.

2.5. Analytical Methods. The decolorization of the synthetic textile effluent was monitored every 24 hours, and it was compared to the biosorption of dyes into the biomass. Decolorization was measured using a UV-visible spectrophotometer (Hitachi U2000), and biosorption was determined by methanol extraction [15]. The COD, BOD, TDS,
TKN, MLSS, MLVSS, hardness, and chloride were determined using standard methods [20].

2.6. Analysis of Degraded Metabolites. The metabolites formed after anaerobic and sequential anaerobic-aerobic treatment of the mixed azo dyes were analyzed through FTIR, HPLC, and GC-MS analyses. The extraction of these metabolites was carried out using ethyl acetate, after which they were condensed in a rotary vacuum evaporator. The condensed sample was filtered through a $0.45 \mu$ syringe filter and was used for the analyses. The metabolites in the degraded sample were compared to those found in control (untreated effluent).

2.7. Phytotoxicity of Secondary Sludge. The sludge that remained in the reactor after the synthetic textile effluent was referred to as secondary sludge. The effects of this secondary sludge on plant growth were identified through a phytotoxicity assay [21]. The secondary sludge from the AnSBR and MBBR was mixed with garden soil in equal volumes, watered, and incubated for two days in outdoor conditions (test). About twelve seeds of Vigna unguiculata (cowpea) were sowed in this prepared mixture and watered at 24-hour intervals with tap water. A control pot was maintained which contained only garden soil. After ten days, the root and shoot length and the percentage of germination were calculated for both pots, and the results were compared. The percentage of germination was calculated using the following formula: 


$$
\text { Germination }(\%)=\frac{\text { Number of seeds germinated }}{\text { Number of seeds sown }} \times 100 \text {. }
$$

\section{Results and Discussion}

3.1. An-SBR with $100 \mathrm{mg} / \mathrm{L}$ of Mixed Azo Dyes. The decolourization was monitored daily, and its proportionality to biosorption also was determined. The effluent showed $76 \%$ removal of mixed azo dyes within 24 hours. Notably, mixed azo dyes' biosorption into the biomass was also high at 24 hours, $0.683 \mathrm{mg} / \mathrm{g}$. At 48 hours, there was a $2 \%$ drop in the decolourization, which can be linked to the subsequent drop in biosorption at 48 hours. The highest percentage of decolourization for mixed azo dyes was obtained on the fourth day, $89 \%$, proportional to the peak in biosorption, $1.124 \mathrm{mg} / \mathrm{g}$, as depicted in Figure 2. On the fifth day, there was a drop in both the percentage of decolourization and biosorption. The decolourization percentage's stability despite changes in the biosorption levels points out an alternate decolourization method occurring in the synthetic effluent. This method may be through the anaerobic reduction of the azo bond by enzymes released by facultative and obligate anaerobes present in the biomass. Mathur et al. [22] also reported removing azo dyes by biosorption using the fungus Aspergillus lentulus. They were able to obtain approximately 97\% of Reactive Yellow and Reactive Blue's removal at low concentrations $(25-50 \mathrm{mg} / \mathrm{L})$.

The reactor was initially loaded with synthetic wastewater having a BOD of $360 \mathrm{mg} / \mathrm{L}$. The BOD removal efficiency was $46 \%$ initially, reducing the influent BOD to $192 \mathrm{mg} / \mathrm{L}$ within 24 hours. The BOD removal efficiency increased to $65 \%$, as the value was lowered to $126 \mathrm{mg} / \mathrm{L}$ at the end of the first cycle. The final BOD removal efficiency was $73 \%$, with the effluent BOD value at $96 \mathrm{mg} / \mathrm{L}$. The dynamic removal of $\mathrm{BOD}$ from the synthetic effluent proves the microorganisms' efficient acclimatization to the synthetic wastewater. The influent COD was $560 \mathrm{mg} / \mathrm{L}$, and this reduced to $420 \mathrm{mg} / \mathrm{L}$ towards the end of the first cycle, indicating only partial acclimatization of the microorganisms to the dyes. In the second and third cycles, however, the COD removal efficiency was as high as $69 \%$, and a final COD concentration of $180 \mathrm{mg} / \mathrm{L}$ was obtained at the end of the third cycle. A positive correlation was observed between HRT and COD removal. The results were found to agree with Isik and Sponza [23], who reported an increase in COD removal from $26 \%$ to $40.8 \%$ by increasing the HRT from 3 to 30 hours in the treatment of Congo Red Reactive Black 5 at a concentration of $100 \mathrm{mg} / \mathrm{L}$. Ong et al. [24] also reported an increase in decolourization from $82 \%$ to $97 \%$ and COD removal from $27 \%$ to $35 \%$ when HRT was increased from 24 hours to 48 hours. A different observation was reported by Sen and Demirer [25] where the COD and BOD removal efficiencies dropped from $70 \%$ to $35 \%$ and $78 \%$ to $39 \%$, respectively, when HRT was increased from 24 hours to 50 hours.

The synthetic effluent's initial hardness was $225 \mathrm{mg} / \mathrm{L}$, which showed a decline to $120 \mathrm{mg} / \mathrm{L}$ within 24 hours and remained stable for another 24 hours. It then increased to $170 \mathrm{mg} / \mathrm{L}$, which may be caused due to precipitation of calcium salts. The final hardness was $60 \mathrm{mg} / \mathrm{L}$. The chloride content was very high in the influent, $500 \mathrm{mg} / \mathrm{L}$, and it dropped to $170 \mathrm{mg} / \mathrm{L}$ within the first 24 hours, indicating a high chloride removal efficiency of $66 \%$. The changes in physicochemical parameters are depicted in Figure 3.

The influent TDS of the synthetic effluent was $2000 \mathrm{mg} /$ L. The overall TDS removal efficiency was $90 \%$, and a final TDS value of $200 \mathrm{mg} / \mathrm{L}$ was achieved towards the end of cycle three. The concentration peaked at days five and nine when a fresh influent was added to the system. The influent MLSS was $4000 \mathrm{mg} / \mathrm{L}$, and MLVSS was $1000 \mathrm{mg} / \mathrm{L}$. 75\% reduction was noted in the MLSS value giving a final concentration of $1000 \mathrm{mg} / \mathrm{L}$. The concentration dropped from 1000 to $800 \mathrm{mg} / \mathrm{L}$ in 48 hours but again rose to $1900 \mathrm{mg} / \mathrm{L}$ at 72 hours. The final MLVSS concentration was $2000 \mathrm{mg} / \mathrm{L}$. The increase in the concentrations of MLSS and MLVSS throughout the operation may be attributed to the fact that microorganisms degrade dyes to organic material and water [26-28]. The changes in TDS, MLSS, and MLVSS are depicted in Figure 4.

3.2. An-SBR with $500 \mathrm{mg} / \mathrm{L}$ of Mixed Azo Dyes. The highest percentage of decolourization was observed on the first day of cycle one (68\%). Beyond day 1, there were constant fluctuations in the decolourization, which was fairly proportional to those in biosorption (Figure 5). The highest value of biosorption was noted on day 6 when $24.65 \mathrm{mg} / \mathrm{g}$ of mixed azo dyes was absorbed into the sludge. The decolorization percentage was raised in agreement with biosorption to $68.1 \%$.

The influent's COD was $872 \mathrm{mg} / \mathrm{L}$, which decreased to $380 \mathrm{mg} / \mathrm{L}$ at the end of the first cycle. The COD removal efficiency on the first day was only $15 \%$, which decreased further on day two and finally increased to $56 \%$ towards the end of the cycle. The second cycle's COD removal efficiency increased steadily from $14 \%$ on day 1 to $54 \%$ on day 4 . In the third cycle, the COD removal efficiency was $6 \%$ on day 1 and $52 \%$ on day 4 . The initial BOD of the influent was $520 \mathrm{mg} / \mathrm{L}$, which decreased to $370 \mathrm{mg} / \mathrm{L}$ towards the end of the first cycle, corresponding to a BOD removal efficiency of $28 \%$. This efficiency significantly increased in cycles two and three, which were $66 \%$ and $78 \%$, respectively. The effect of increased concentration of dyes on the treatment efficiency was noted. These results agreed with the results obtained by Yadav et al. [29], and Baeta et al. [14], Li et al [30], Lourenco [31], Maas and Chaudhari [32, 33] reported a decrease in treatment efficiency by increasing the dye concentration. Chen et al. [34] also reported a higher decolorization percentage for removing Alizarin Yellow R (85.7\% and 66.8\%) at concentrations of $50 \mathrm{mg} / \mathrm{L}$ and $200 \mathrm{mg} / \mathrm{L}$ of the dye. At $400 \mathrm{mg} / \mathrm{L}$, no decolorization was found to occur. Baeta et al. [14] reported that the possible reason for treatment inefficiency is an increase in wastewater toxicity and an increase in toxic load, which is caused due to increasing dye concentration. 


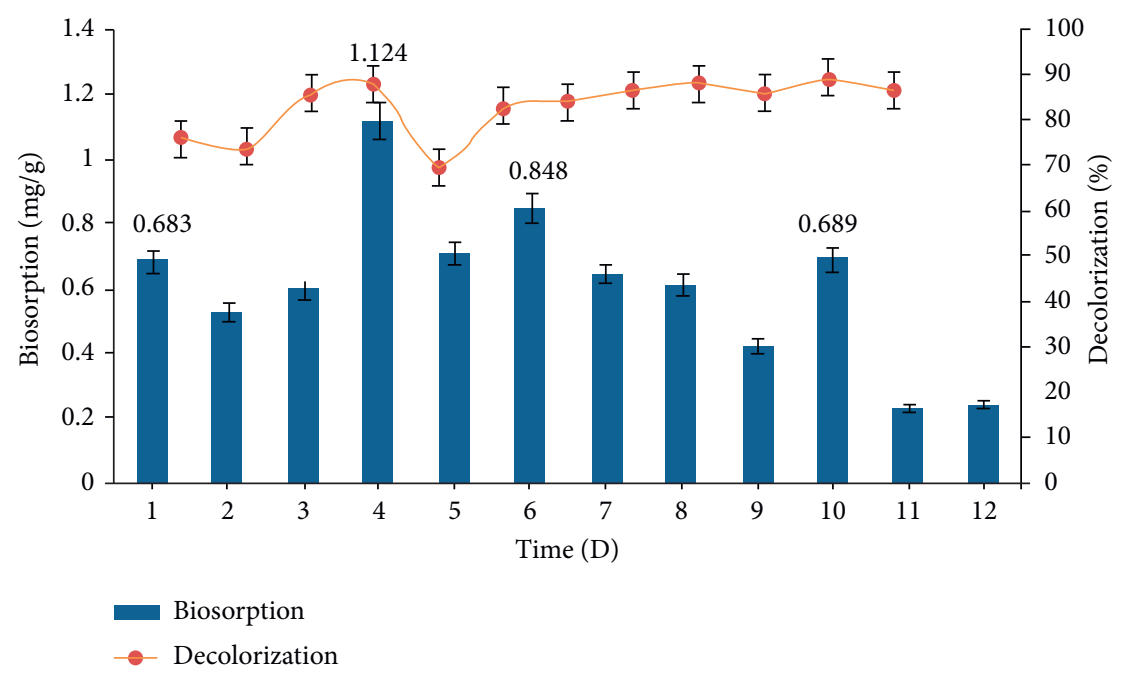

Figure 2: Proportionality of biosorption to the percentage of decolorization in the anaerobic treatment of synthetic textile effluent containing $100 \mathrm{mg} / \mathrm{L}$ of mixed azo dyes in An-SBR.

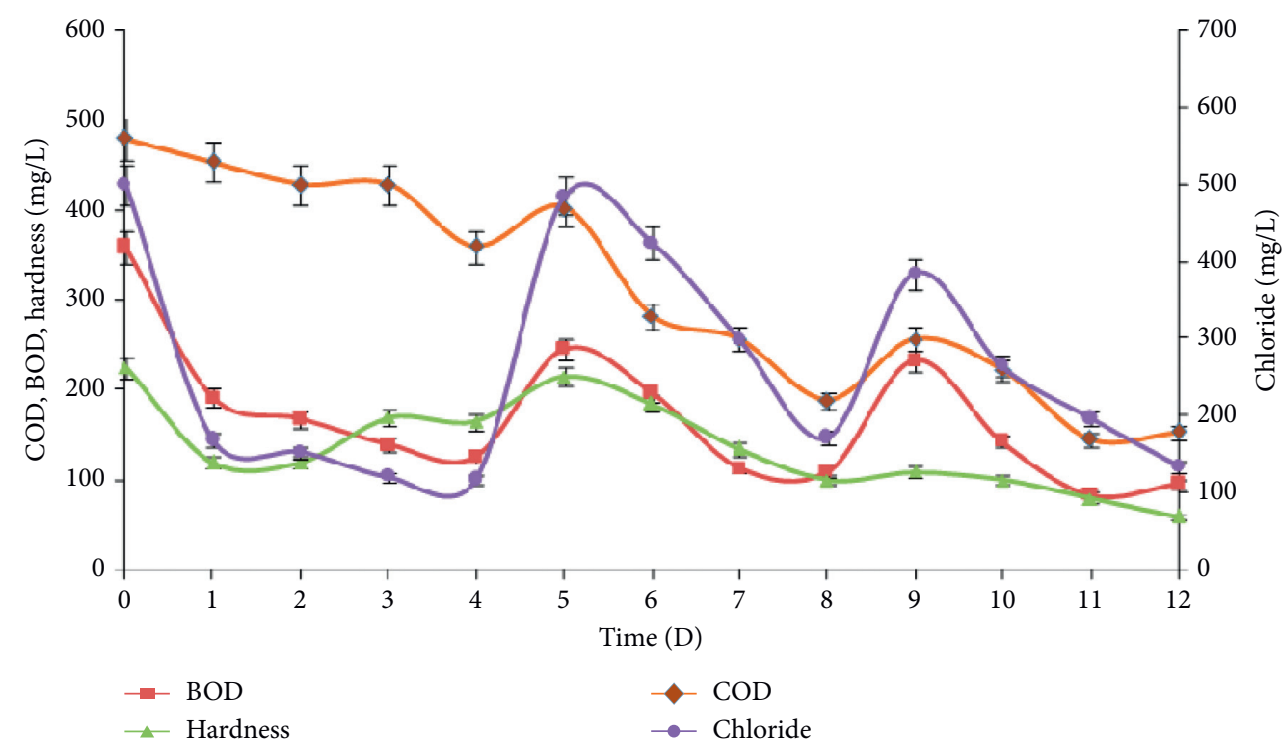

FIgURE 3: Removal of COD, BOD, chloride, and hardness in the anaerobic treatment of synthetic textile effluent containing $100 \mathrm{mg} / \mathrm{L}$ of mixed azo dyes in An-SBR.

The influent's hardness was $400 \mathrm{mg} / \mathrm{L}$, and this was reduced to $200 \mathrm{mg} / \mathrm{L}$ towards the end of the first cycle. Chloride values were too high in the influent $1250 \mathrm{mg} / \mathrm{L}$, which is due to the textile industry's several processes that utilize chlorine compounds. The treatment showed high chloride removal efficiency (76\%), with the final chloride concentration being $300 \mathrm{mg} / \mathrm{L}$. The changes in the physicochemical parameters are depicted in Figure 6.

The initial TDS was $3500 \mathrm{mg} / \mathrm{L}$ and decreased to $1000 \mathrm{mg} / \mathrm{L}$ towards the end of cycle one, corresponding to a TDS removal of $71 \%$. The second cycle showed a steady decrease in the TDS from $3500 \mathrm{mg} / \mathrm{L}$ to $1900 \mathrm{mg} / \mathrm{L}$ on the third day, after which the TDS value increased to $2500 \mathrm{mg} / \mathrm{L}$ towards the end of the cycle. The third cycle again showed a stable decrease in the TDS with a removal efficiency of $52 \%$.
The MLSS and MLVSS showed several fluctuations over the three cycles. These are caused mainly due to the continual formation and breakdown of dye metabolites absorbed into the sludge, which led to an increase and decrease in MLSS and MLVSS. The initial MLSS was $5500 \mathrm{mg} / \mathrm{L}$, which towards the end of three cycles reduced to $2000 \mathrm{mg} / \mathrm{L}$. The MLVSS was $1800 \mathrm{mg} / \mathrm{L}$ at loading, and the final value was $1300 \mathrm{mg} / \mathrm{L}$. The changes in MLSS and MLVSS also confirm the degradation of azo dyes by the microbial consortium to produce metabolites that are absorbed into the sludge. The changes in TDS, MLSS, and MLVSS are depicted in Figure 7. Textile Effluent in $A n-S B R$ and $M B B R$. The sequential 


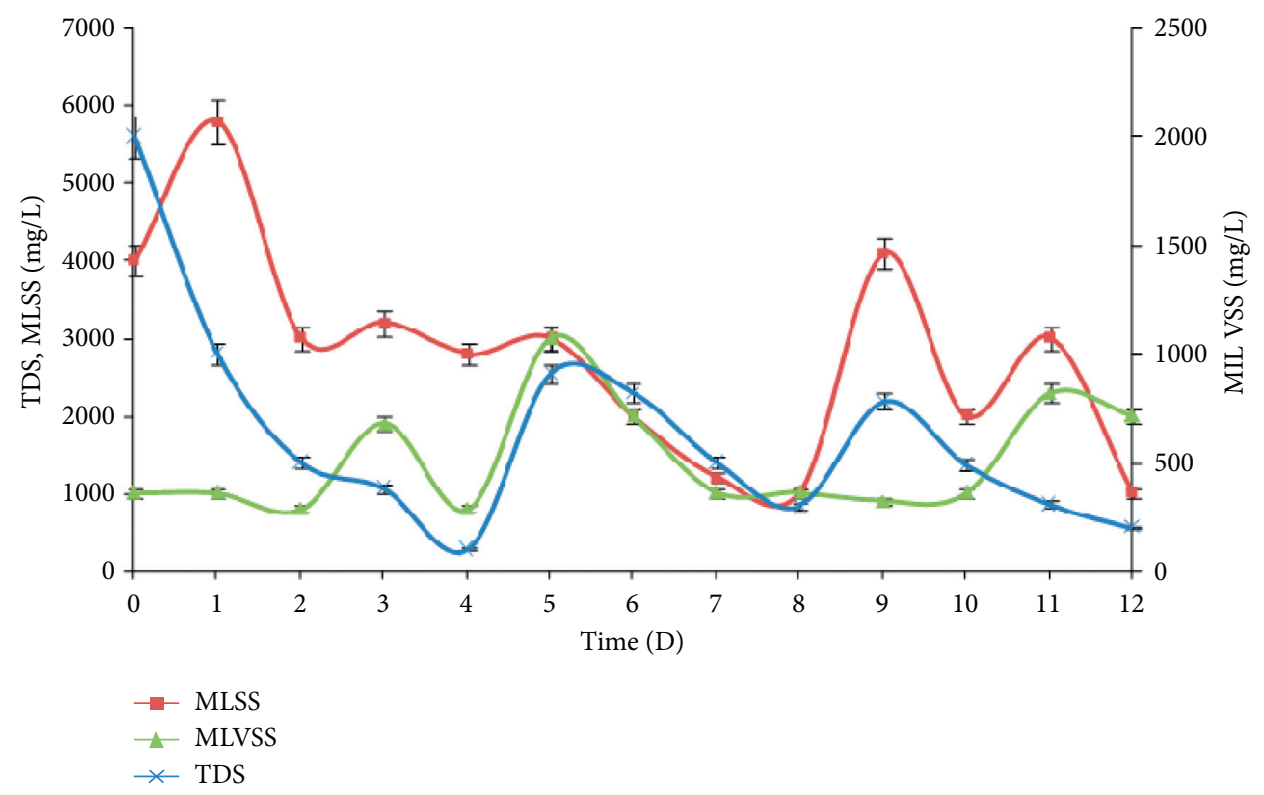

FIGURE 4: Removal of TDS, MLSS, and MLVSS in the anaerobic treatment of synthetic textile effluent containing $100 \mathrm{mg} / \mathrm{L}$ of mixed azo dyes in An-SBR.

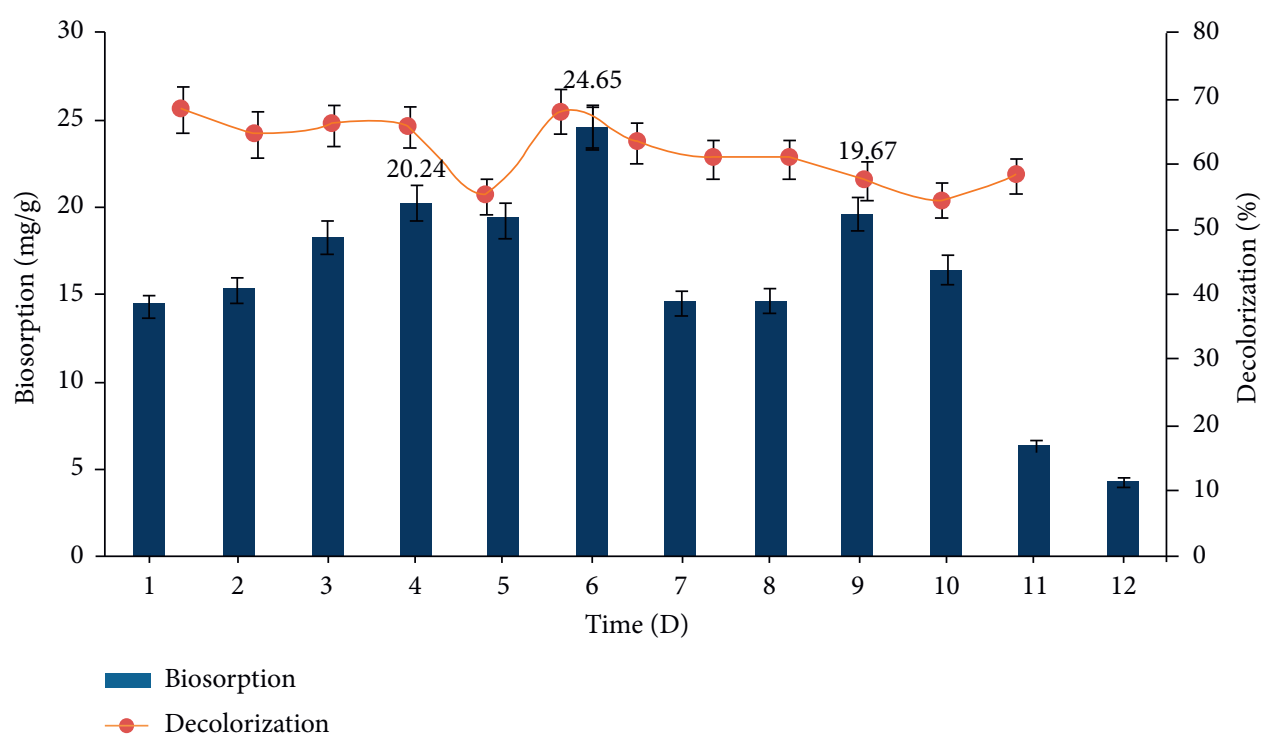

FIgURe 5: Proportionality of biosorption to the percentage of decolorization in the anaerobic treatment of synthetic textile effluent containing $500 \mathrm{mg} / \mathrm{L}$ of mixed azo dyes in An-SBR.

anaerobic-aerobic treatment of textile effluent was carried out in An-SBR, followed by aerobic treatment in MBBR. The bioreactors were operated for two cycles, each cycle comprising 96 hours. The first cycle was operated with synthetic textile effluent containing $100 \mathrm{mg} / \mathrm{L}$ of mixed azo dyes and the second with $500 \mathrm{mg} / \mathrm{L}$ of mixed azo dyes.

The decolourization was monitored every 24 hours through UV-visible spectroscopy, and biosorption of dyes into the biomass was also determined. The decolourization percentage of mixed azo dyes towards the end of the anaerobic phase of the first cycle (with $100 \mathrm{mg} / \mathrm{L}$ of mixed azo dyes) was $97 \%$, which dropped to $96 \%$ in the aerobic phase and again rose to $98 \%$. This indicates that the maximum color removal occurred during the anaerobic phase and was insignificant during the cycle's aerobic phase (Figure S3a). A similar pattern of color removal was observed during the second cycle (with $500 \mathrm{mg} / \mathrm{L}$ of mixed azo dyes). Castro et al. [35] studied Reactive Orange 16's removal under aerobic conditions using MBBR and reported $0 \%$ decolourization.

It was observed that the biosorption was more significant in the anaerobic conditions than under aerobic conditions in both concentrations of mixed azo dyes. In the first cycle, the highest anaerobic biosorption was $2.02 \mathrm{mg} / \mathrm{g}$, while in the aerobic phase, it was $1.85 \mathrm{mg} / \mathrm{g}$. The difference was much 


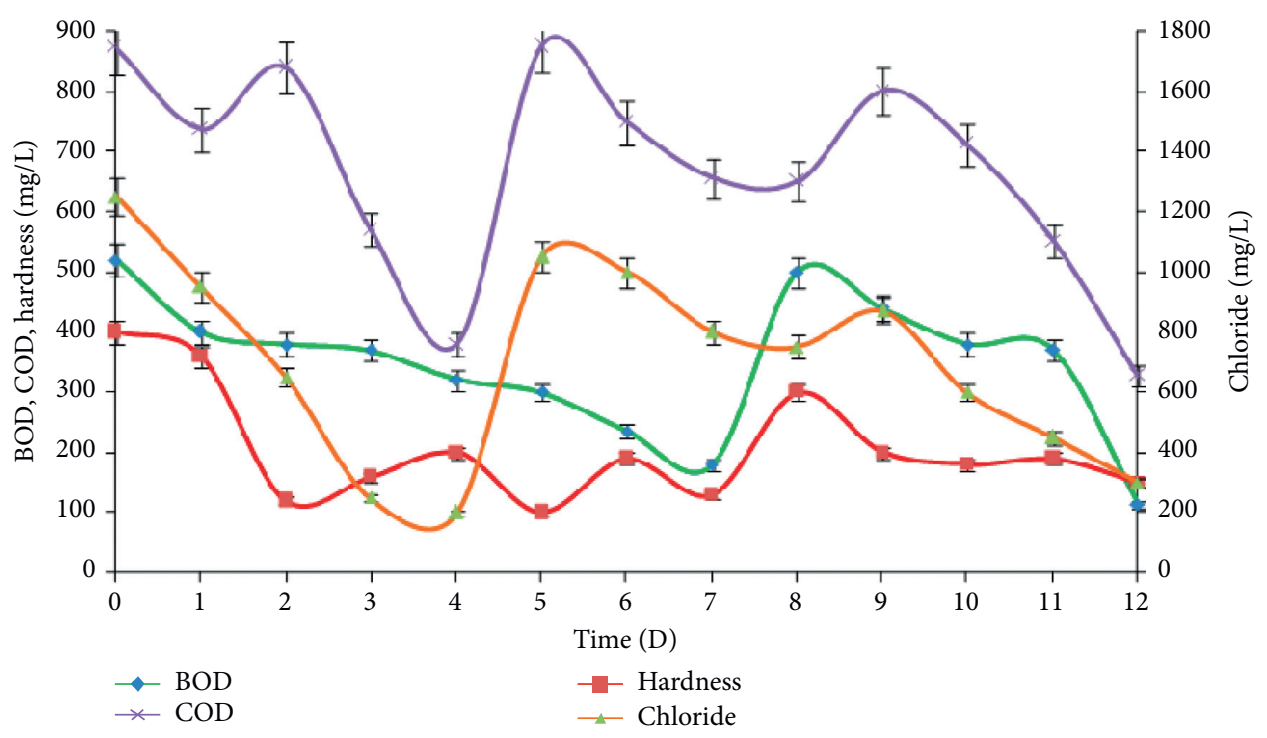

Figure 6: Removal of COD, BOD, chloride, and hardness in the anaerobic treatment of synthetic textile effluent containing $500 \mathrm{mg} / \mathrm{L}$ of mixed azo dyes in An-SBR.

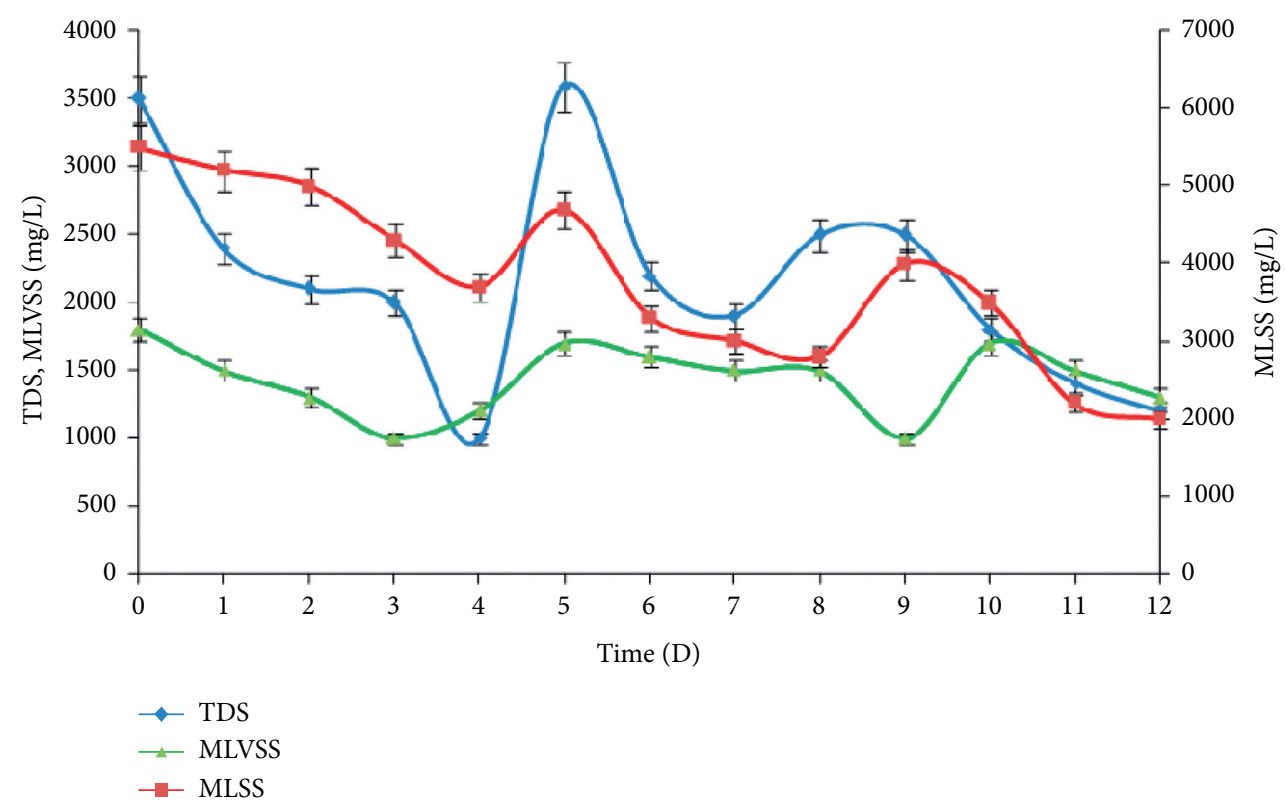

FIGURE 7: Removal of TDS, MLSS, and MLVSS in the anaerobic treatment of synthetic textile effluent containing $500 \mathrm{mg} / \mathrm{L}$ of mixed azo dyes in An-SBR.

more significant in the second cycle, with the highest anaerobic biosorption value being $19.14 \mathrm{mg} / \mathrm{g}$, while the aerobic value being $10.22 \mathrm{mg} / \mathrm{g}$ (Figure S3(b)). The possible reason for this may be the high value of decolorization in the anaerobic phase, thus reducing the concentration of azo dyes significantly before it is passed on to the aerobic phase [36].

During the first cycle, the initial COD was $580 \mathrm{mg} / \mathrm{L}$, which was reduced to $320 \mathrm{mg} / \mathrm{L}$ at the end of the anaerobic phase and further to $275 \mathrm{mg} / \mathrm{L}$ at the end of the aerobic phase. This corresponds to a total removal efficiency of 53\%, which was found to be lesser than the removal efficiency of the exclusively anaerobic cycle. The reason could be the shorter anaerobic hydraulic retention time (HRT), which was only 48 hours in the sequential process compared to 96 hours in the complete anaerobic treatment. In the second cycle, the COD was reduced from $1000 \mathrm{mg} / \mathrm{L}$ to $856 \mathrm{mg} / \mathrm{L}$, corresponding to only $14 \%$ COD removal. A similar observation was made by Isik and Sponza [37]. They reported more than $70 \%$ reduction in COD and $98 \%$ color removal in the anaerobic phase of the sequential anaerobic-aerobic treatment of $100 \mathrm{mg} / \mathrm{L}$ of Reactive Black 5 and Congo Red. Tabassum et al. [30] also reported more than 69.5\% COD 
removal in the treatment of coal gasification water in an anaerobic SBR after 24 hours of anaerobic treatment.

During cycle one, the initial BOD was $350 \mathrm{mg} / \mathrm{L}$, which decreased to $190 \mathrm{mg} / \mathrm{L}$ at the end of the anaerobic phase and then to $100 \mathrm{mg} / \mathrm{L}$ towards the end of the aerobic phase. During cycle two, the initial BOD was $500 \mathrm{mg} / \mathrm{L}$, which decreased to $270 \mathrm{mg} / \mathrm{L}$ at the end of the anaerobic phase and then to $180 \mathrm{mg} /$ L. Therefore, the BOD removal efficiency during the first cycle was $71 \%$, and it was $64 \%$ during the second cycle. This efficiency was comparable to that observed in the exclusively anaerobic process, which was approximately $69 \%$ when operated with $100 \mathrm{mg} / \mathrm{L}$ and $72 \%$ with $500 \mathrm{mg} / \mathrm{L}$ of mixed azo dyes. Therefore, BOD removal was not significantly different in the sequential anaerobic-aerobic process compared to the exclusively anaerobic process.

The hardness removal efficiency in the first cycle was $40 \%$ after the anaerobic phase and $72 \%$ after aerobic treatment. The final hardness of the treated effluent from the first cycle was $70 \mathrm{mg} / \mathrm{L}$, and it was $400 \mathrm{mg} / \mathrm{L}$ in the second cycle. The hardness removal efficiency in the second cycle was $73 \%$ after anaerobic and aerobic treatment. Thus, both cycles' hardness removal efficiency was observed to be reasonably constant despite the difference in concentrations of mixed azo dyes. The initial chloride content was $500 \mathrm{mg} / \mathrm{L}$ in the first cycle and $2000 \mathrm{mg} / \mathrm{L}$ in the second cycle, which reduced to $240 \mathrm{mg} / \mathrm{L}$ and $1100 \mathrm{mg} / \mathrm{L}$, respectively, at the end of the anaerobic phase. The concentration further decreased to $100 \mathrm{mg} / \mathrm{L}$ and $400 \mathrm{mg} / \mathrm{L}$ at the end of the aerobic phases in cycles one and two. This corresponds to a chloride removal efficiency of $80 \%$ in both cycles one and two. Therefore, in the sequential process, the chloride removal efficiency was unaltered by increased dye concentration. The changes in the physicochemical parameters are represented in Figure 8.

The initial concentration of TDS in cycle one was $2400 \mathrm{mg} / \mathrm{L}$, which was effectively reduced to $400 \mathrm{mg} / \mathrm{L}$ towards the end of the cycle with an approximate efficiency of $83 \%$. In the second cycle, the TDS reduced from $3200 \mathrm{mg} / \mathrm{L}$ to $800 \mathrm{mg} / \mathrm{L}$ and corresponds to an efficiency of $75 \%$. The reduction efficiency was reduced as a result of the increase in the concentration of mixed azo dyes. However, when compared to the exclusively anaerobic process, the TDS reduction in cycle one (with $100 \mathrm{mg} / \mathrm{L}$ mixed azo dyes) was lesser in the sequential process but was found to be higher in the second cycle (with $500 \mathrm{mg} / \mathrm{L}$ of mixed azo dyes) and is represented in Figure 9.

The MLSS and MLVSS concentrations decreased gradually as the cycle proceeded. The effective reduction was observed in both anaerobic and aerobic phases of both cycles. At the beginning of cycle one, the MLSS concentration was $4000 \mathrm{mg} / \mathrm{L}$, which decreased to $800 \mathrm{mg} / \mathrm{L}$ and the MLVSS concentration decreased from $1000 \mathrm{mg} / \mathrm{L}$ to $400 \mathrm{mg} /$ L towards the end of the cycle. In the second cycle, the MLSS concentration decreased from $3600 \mathrm{mg} / \mathrm{L}$ to $1700 \mathrm{mg} / \mathrm{L}$ and the MLVSS concentration decreased from $1400 \mathrm{mg} / \mathrm{L}$ to $700 \mathrm{mg} / \mathrm{L}$. The decline was gradual, and removal efficiency was found to be much higher in cycle one than in cycle two. The results obtained were comparable with Al-Amrani et al. [38], who reported a decrease in MLSS concentration from $2500 \mathrm{mg} / \mathrm{L}$ to $1000 \mathrm{mg} / \mathrm{L}$ from the first run to the third run.
3.4. Removal of Total Kjeldahl Nitrogen (TKN). The removal of total Kjeldahl nitrogen was monitored at the beginning and conclusion of each cycle during the complete anaerobic treatment and the sequential anaerobic-aerobic treatment. The initial value of TKN with $100 \mathrm{mg} / \mathrm{L}$ of mixed azo dyes was $316.85 \mathrm{mg} / \mathrm{L}$, which reduced to $304.01 \mathrm{mg} / \mathrm{L}$ after anaerobic treatment in An-SBR, corresponding to a removal efficiency of $4.05 \%$. This efficiency was increased to $15 \%$ when the concentration of azo dyes was increased to $500 \mathrm{mg} /$ L. In the sequential anaerobic-aerobic treatment, the TKN removal with $100 \mathrm{mg} / \mathrm{L}$ of mixed azo dyes was found to be only $1.01 \%$, and with $500 \mathrm{mg} / \mathrm{L}$ of mixed azo dyes, it was $12.5 \%$ (Figure S4). Therefore, the removal efficiency was generally found to increase with dye concentration and was observed to be higher in the complete anaerobic process than in the sequential anaerobic-aerobic process.

3.5. Analysis of the Dye-Related Metabolites. The degradation of mixed azo dyes and the formation of various dye-related metabolites were analyzed through FT-IR, HPLC, and GC-MS analyses.

3.5.1. FT-IR Analysis. The FT-IR spectrum of $100 \mathrm{mg} / \mathrm{L}$ of mixed azo dyes (standard) ranges from 4000 to $400 \mathrm{~cm}^{-1}$. Two distinct peaks were observed: one at $1636 \mathrm{~cm}^{-1}$ and another at $3326 \mathrm{~cm}^{-1}$. The broader peak at $3326 \mathrm{~cm}^{-1}$ corresponds to the $\mathrm{O}-\mathrm{H}$ stretching vibrations, representing the presence of water in which the azo dye was dissolved. The sharp peak at $1636 \mathrm{~cm}^{-1}$ corresponds to the $\mathrm{C}=\mathrm{C}$ stretching indicating the presence of nondegraded azo dyes used in the study and the absence of other aromatic metabolites (Figure S5(a)).

The FT-IR analysis of the synthetic effluent containing $100 \mathrm{mg} / \mathrm{L}$ of mixed azo dyes posttreatment in the An-SBR shows multiple peaks of varying intensities in the range of $4000-400 \mathrm{~cm}^{-1}$. The two medium intensity peaks in the frequency range $3000-4000 \mathrm{~cm}^{-1}$ correspond to $\mathrm{N}-\mathrm{H}$ and $\mathrm{C}-\mathrm{H}$ stretching vibrations. $\mathrm{C}-\mathrm{N}$ stretching was also noted from the medium peak at 1104.62, and this stretching indicates the anaerobic breakdown of azo dyes into aromatic amines. The medium peak at $1636.97 \mathrm{~cm}^{-1}$ corresponds to $\mathrm{C}=\mathrm{C}$ stretching vibration indicating the presence of alkenes. The strong peak at $1400.36 \mathrm{~cm}^{-1}$ corresponding to $\mathrm{S}=\mathrm{O}$ stretching vibration points out the presence of sulfate, which results as a breakdown product of the mixed azo dyes proving the degradation of azo dyes during the effluent treatment (Figure S5(b)).

The FT-IR analysis of the synthetic effluent containing $500 \mathrm{mg} / \mathrm{L}$ of mixed azo dyes posttreatment in An-SBR reveals a broad medium peak at $3443.39 \mathrm{~cm}^{-1}$ represents $\mathrm{O}-\mathrm{H}$ stretching. Multiple bands of medium intensity were observed in the range of $1650-500 \mathrm{~cm}^{-1}$. The medium sharp peak in the region $1400.64 \mathrm{~cm}^{-1}$ corresponds to $\mathrm{O}-\mathrm{H}$ bending in carboxylic acids, a metabolite produced in the anaerobic degradation of mixed azo dyes (Figure S5(c)). The peak in the region of $1651.83 \mathrm{~cm}^{-1}$ represents $\mathrm{C}=\mathrm{C}$ stretching vibrations, which indicates the presence of alkenes. Telke et al. [39] reported $\mathrm{C}-\mathrm{N}, \mathrm{C}=\mathrm{C}$, and $\mathrm{N}-\mathrm{H}$ 


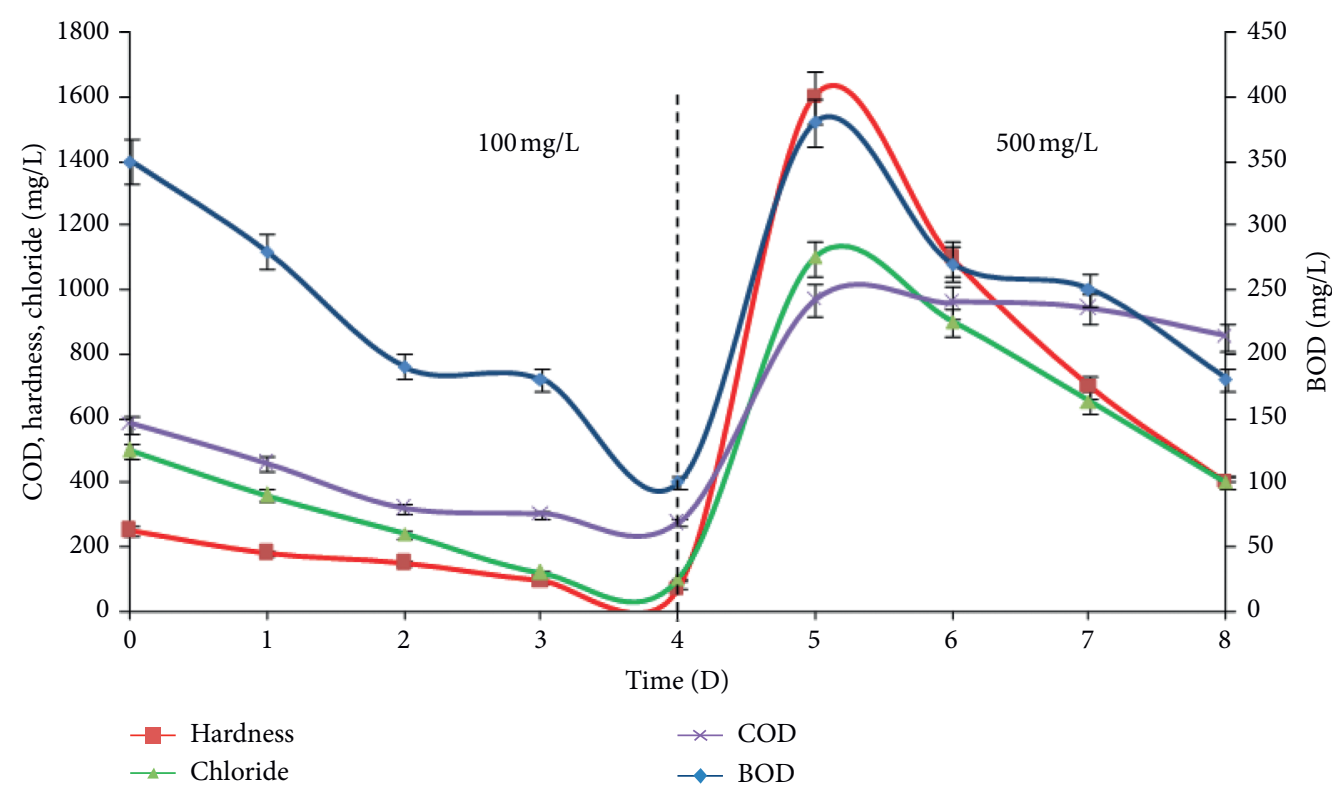

FIGURE 8: Removal of BOD, COD, hardness, and chloride in the sequential anaerobic-aerobic treatment processes carried out in the An-SBR and aerobic MBBR.

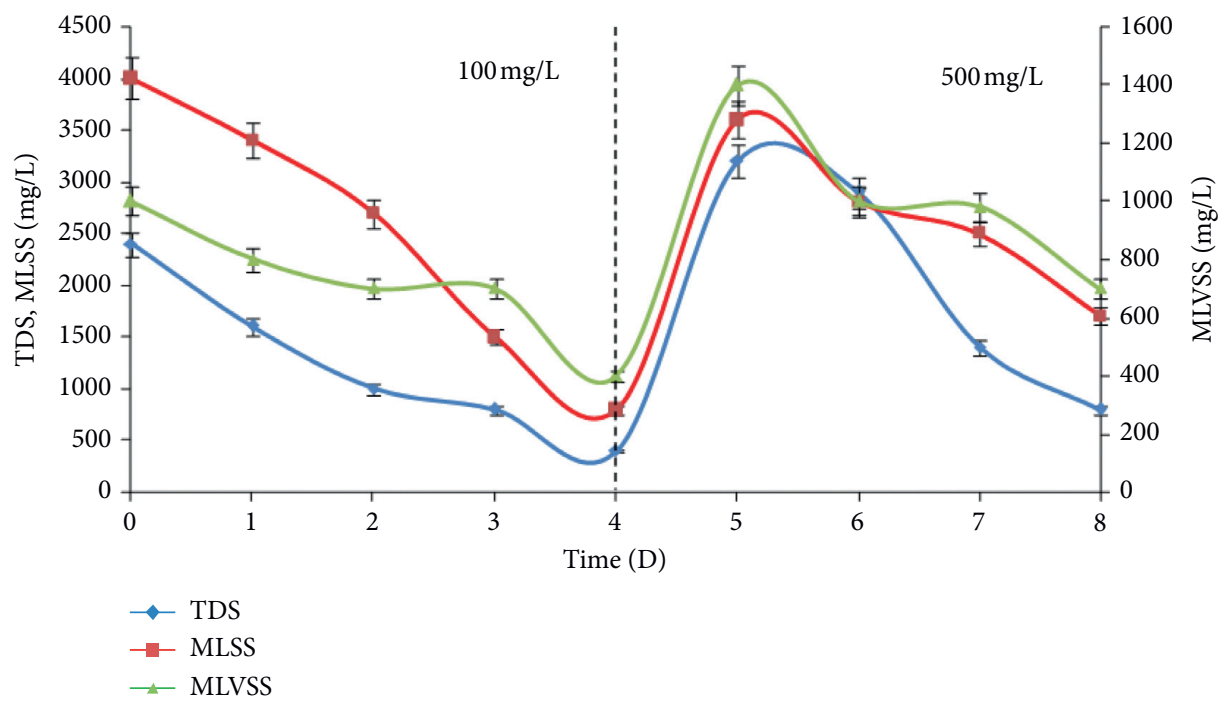

FIGURE 9: Removal of TDS, MLSS, and MLVSS in the sequential anaerobic-aerobic treatment processes carried out in the An-SBR and aerobic MBBR.

stretching vibrations corresponding to the formation of primary amines in the FT-IR spectrum of treated Congo Red dye. These bonds' presence was also noted in the present study, thus confirming the breakdown of mixed azo dyes into aromatic amines. The functional group and their corresponding compounds were analyzed through FT-IR in the standard, and treated effluents are listed in Table 2.

3.5.2. HPLC Analysis. The metabolites produced due to the degradation of mixed azo dyes were observed through HPLC analysis at $248 \mathrm{~nm}$. A comparison of the untreated effluent and the effluents treated in An-SBR (anaerobic effluent) and MBBR (aerobic effluent) revealed the degradation of mixed azo dyes formation of several metabolites. The elution profile of the untreated effluent containing $100 \mathrm{mg} / \mathrm{L}$ of mixed azo dyes comprised three peaks, two of which were intense and observed at a retention time of 2.876 and 3.192 minutes and a shorter peak at 4.275 minutes (Figure S6).

The anaerobic effluent after 96 hours of treatment in An-SBR showed complete degradation of the peaks at 2.876 and 3.192 minutes. An intense peak was observed at 4.203 and shorter peaks at 5.197, 5.459, 5.629, and 7.793 minutes, which indicate the breakdown of the dyes into various metabolites, including aromatic amines. 
TABLE 2: Functional groups and compounds observed through FTIR analysis.

\begin{tabular}{|c|c|c|}
\hline Peak Value & Intensity & Functional group \\
\hline \multicolumn{3}{|c|}{$100 \mathrm{mg} / \mathrm{L}$ mixed Azo dyes standard } \\
\hline 1636 & Strong & $\mathrm{C}=\mathrm{C}$ \\
\hline 3326 & Broad, strong & $\mathrm{O}-\mathrm{H}$ \\
\hline \multicolumn{3}{|c|}{ Treated effluent $(100 \mathrm{mg} / \mathrm{L})$} \\
\hline 3448.44 & Strong, broad & $\mathrm{N}-\mathrm{H}$ \\
\hline 3160.58 & Strong & $\mathrm{C}-\mathrm{H}$ \\
\hline 1104.62 & Medium & $\mathrm{C}-\mathrm{N}$ \\
\hline 1636.97 & Medium & $\mathrm{C}=\mathrm{C}$ \\
\hline 1400.36 & Strong & $\mathrm{S}=\mathrm{O}$ \\
\hline \multicolumn{3}{|c|}{ Treated effluent $(500 \mathrm{mg} / \mathrm{L})$} \\
\hline 3443.39 & Broad, medium & $\mathrm{O}-\mathrm{H}$ \\
\hline 1400.64 & Medium, sharp & $\mathrm{O}-\mathrm{H}$ \\
\hline 1651.83 & Medium & $\mathrm{C}=\mathrm{C}$ \\
\hline
\end{tabular}

The elution profile of the aerobic effluent obtained after sequential anaerobic-aerobic treatment in An-SBR and MBBR, respectively, showed a single strong peak at 3.922 and 4.205 minutes and shorter peaks at 5.232, 5.570, 6.210, $6.316,6.702,6.514,6.756,11.307,11.523,11.931,11.746$, and 12.034 minutes. The splitting of peaks, shift in their retention times, and decreased peak intensities indicate the metabolites' degradation formed in the anaerobic treatment to more specific products in the aerobic phase. The elution profile of anaerobic and aerobic effluent is depicted in Figures 10(a) and 10(b). These observations were similar to the results obtained by Supaka et al. [40] in the HPLC analysis of untreated and treated Remazol Black B. The anaerobicaerobic treatment showed peaks that were much less intense, indicating that the metabolites produced were aerobically metabolized to form fewer aromatic and more polar compounds, as observed in the aerobic treatment of Remazol Brilliant Orange 3R by Supaka et al. [40] after 24 hours of anaerobic followed by 12 hours of aerobic incubation.

The HPLC analysis of the anaerobic effluent with $500 \mathrm{mg} / \mathrm{L}$ of mixed azo dyes obtained from An-SBR after 96 hours was found to exhibit two prominent peaks at 3.433 and 3.706 minutes, multiple small peaks. The shift from the standard peak was found at an RT of 2.876 and 3.192 minutes, and changes in intensity confirm the breakdown of dyes and variable dye metabolites.

The aerobic effluent's elution profile from the MBBR after sequential anaerobic-aerobic treatment yielded two peaks at 3.443 and 3.706 minutes with intensities similar to those of the anaerobic effluent. The number of smaller peaks in the aerobic effluent was lesser compared to the anaerobic effluent. The elution profile of anaerobic and aerobic effluent is depicted in Figures 11(a) and 11(b). Koupaie et al. [41] reported complete degradation of the anaerobic peak after aerobic treatment, which occurred only in lower concentration $(100 \mathrm{mg} / \mathrm{L})$ of azo dye Acid Red 18. The higher concentration used in the present study $(500 \mathrm{mg} / \mathrm{L})$, therefore, inhibited the degradation of metabolites formed after anaerobic treatment.

Thus, the sequential treatment in An-SBR and MBBR was found to be more effective than a complete anaerobic treatment at a concentration of $100 \mathrm{mg} / \mathrm{L}$ of mixed azo dyes, as the dye was degraded entirely into several simpler products. However, when the dyes' concentration was increased to $500 \mathrm{mg} / \mathrm{L}$, the efficiencies of the complete anaerobic and sequential anaerobic-aerobic treatments were found to be similar. This may be due to the inhibitory effect of a high concentration of azo dyes on the microbial community, thus lowering their degradation capabilities.

3.5.3. GC-MS Analysis. GC-MS analysis was performed to observe the metabolites formed due to the degradation of the mixed azo dyes. The GC-MS chromatogram of the untreated effluent showed a high-intensity peak at the retention time (RT) of 19.43 minutes, which corresponds to the azo bond region of the dye structure (Figure S7). Two other peaks were observed at RT 17.8 minutes and minutes, which correspond to the azo dyes region that does not bear the azo bond. The GC-MS chromatogram of the 96 hours treated effluent (Figure 12) obtained after sequential anaerobic-aerobic treatment showed several peaks representing the dye-related metabolites formed under anaerobic and aerobic conditions by microbial degradation. The peak corresponding to azo dye in the untreated effluent was notably removed from the treated sample (Table 3).

The metabolites formed were 2-nitro-benzonitrile (RT16.7 minutes), 4-(1,1-dimethylethyl)benzonitrile (RT-17.7 minutes), azobenzene (RT-17.83 minutes), 4-methyl-3,1benzoxazepine 2-carbonitrile (RT-18.85 minutes), guanethidine (RT-19.45 minutes), and 1-oxide 1-phenyl-2-(4methylphenyl)-diazene (RT-20.92 minutes). The formation of several aromatic structures confirms the breakdown of azo dyes into various simpler products. The compounds azobenzene and 1-phenyl-2-(4-methylphenyl)-diazene 1oxide show the presence of the azo bond $(\mathrm{N}=\mathrm{N})$ (Table 4$)$. Therefore, the sequential anaerobic-aerobic treatment could not result in a complete breakdown of the azo bond but resulted in a breakdown of dye structure into smaller ring compounds. This also indicates the possibility of cross-reaction between metabolites and nondegraded azo dye.

Balapure et al. [42] reported nine metabolites after anaerobic degradation, which were aromatic amines. Jayapal et al. [43] reported two compounds: nitrobenzene and benzoic acid as the final metabolites produced from anaerobic degradation of Methyl Red. In the present study, two benzonitriles and one azobenzene compound were observed, which indicates the breakdown of mixed azo dyes in the synthetic effluent.

3.6. Phytotoxicity of Secondary Sludge. The secondary sludge's toxicity remaining after treatment of the synthetic textile effluent was evaluated in a phytotoxicity assay using Vigna unguiculata. The test plants grown in soil mixed with secondary sludge showed only $42 \%$ of germination, whereas the control reported $83 \%$ germination. A delay in the germination was also noted in the secondary sludge, which showed germination only after five days, whereas the control plants started germinating after approximately two days. This indicates that the residual mixed azo dyes and dyerelated metabolites present in the secondary sludge may have 


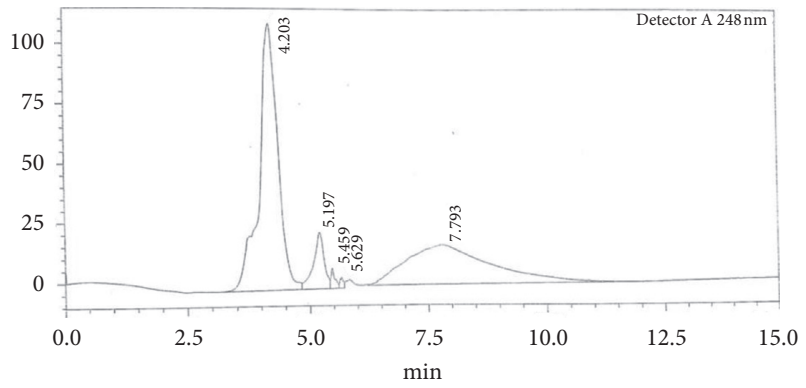

(a)

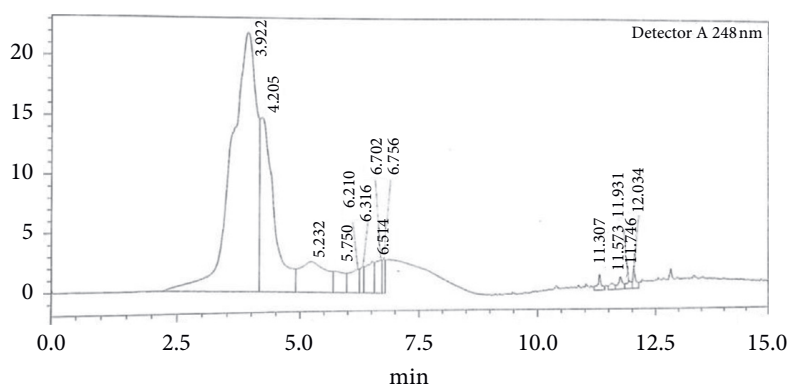

(b)

Figure 10: (a) Elution profile of the An-SBR-treated synthetic textile effluent with $100 \mathrm{mg} / \mathrm{L}$ mixed azo dyes; (b) elution profile of the AnSBR- and MBBR-treated synthetic textile effluent with $100 \mathrm{mg} / \mathrm{L}$ mixed azo dyes.

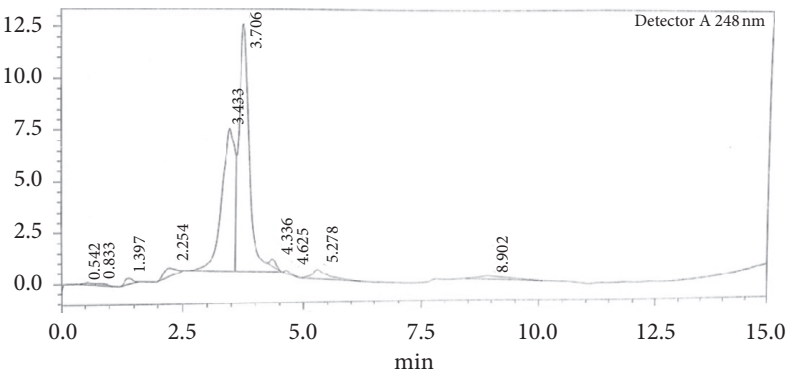

(a)

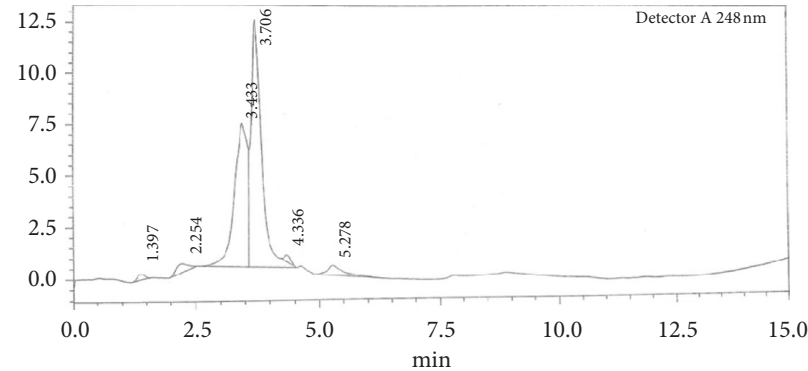

(b)

FIGURE 11: (a) Elution profile of the An-SBR-treated synthetic textile effluent with $500 \mathrm{mg} / \mathrm{L}$ mixed azo dyes; (b) elution profile of the AnSBR- and MBBR-treated synthetic textile effluent with $500 \mathrm{mg} / \mathrm{L}$ mixed azo dyes.

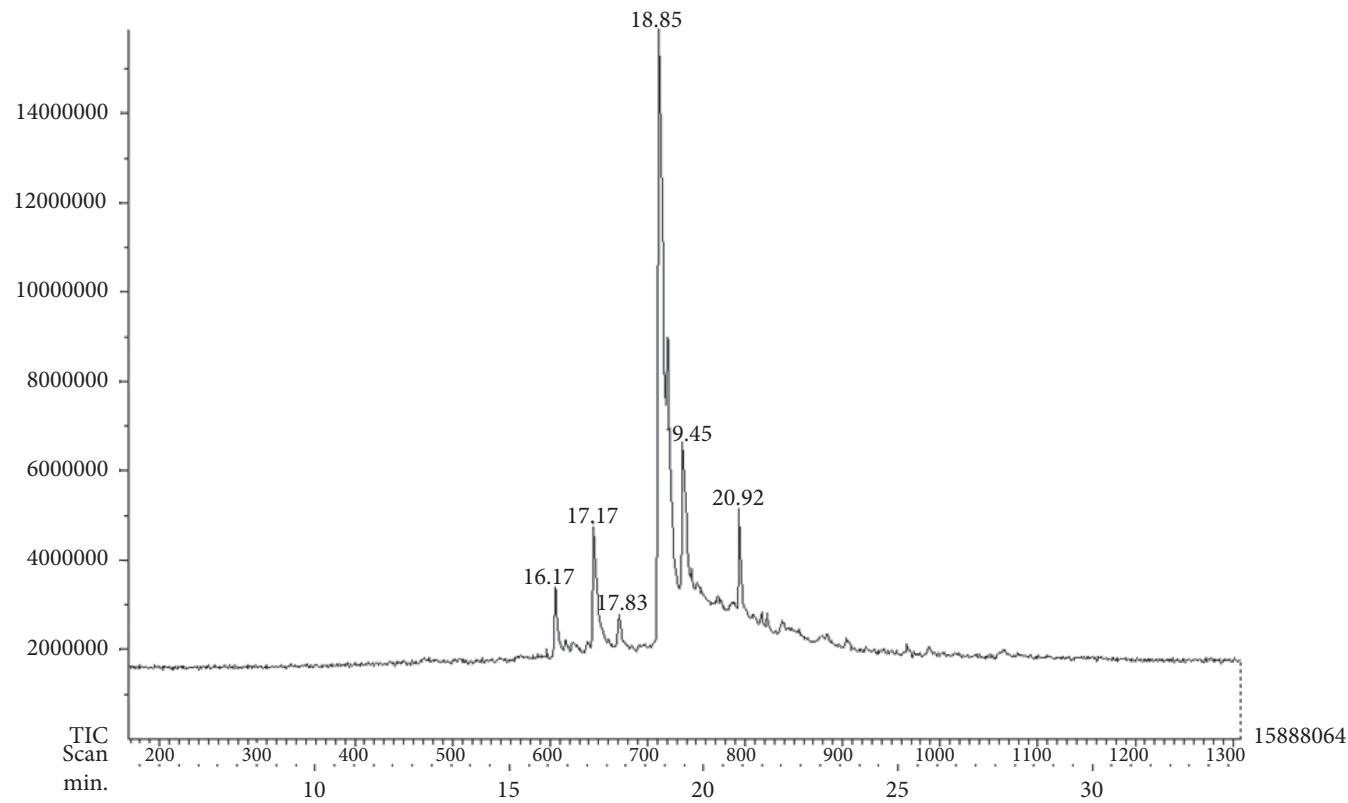

FIGURE 12: GC-MS chromatogram of metabolites formed after degradation of mixed azo dyes postsequential anaerobic-aerobic treatment in An-SBR and MBBR.

exerted a toxic effect on the seeds, thus retarding their germination.

The average root length of the test plants grown in secondary sludge was found to be $2.98 \mathrm{~cm}$, and the average shoot length was found to be $13.38 \mathrm{~cm}$. The control plants had an average root length of $4.96 \mathrm{~cm}$ and an average shot length of $20.51 \mathrm{~cm}$. The approximate difference between the control and test plants' root lengths was $1.98 \mathrm{~cm}$, and the 
TABLE 3: Aromatic compounds present in the untreated synthetic effluent.

Compound name

TABLE 4: Metabolites produced from the degradation of azo dyes in the treated effluent.

Compound name

difference between the shoot lengths was found to be $7.13 \mathrm{~cm}$ (Figures S8(a,b)). Thus, the test plants grown in secondary sludge exhibited a lower percentage of germination and a much shorter root and shoot length than the control plants (Table S1).

Similar observations were made by Kulkarni et al. [1], who studied phytotoxicity using Phaseolus mungo and Sorghum vulgare and reported up to $70 \%$ inhibition of germination when watered with an untreated solution of mixed dyes. Karpagam et al. [44] reported retardation in shoot and root length of Vigna radiata when grown with untreated effluent, which contained mixed azo dyes. In contrast, a $34 \%$ increase in the shoot length of Vigna radiata was observed when it was grown with treated textile effluent. This indicates that, after effective treatment by anaerobic digestion or by phytoremediation, secondary sludge's toxicity can be reduced. It can be successfully used as a fertilizer for plant growth.

\section{Conclusion}

The treatment of textile effluents is critical to ensure the removal of toxic matter and recalcitrant and minimize environmental pollution. Efficient treatment is possible through microbial treatment, particularly by microbial consortia, integrated with bioreactors. The hydraulic 
retention time (HRT) was found to significantly affect the removal of color, COD, BOD, TDS, hardness, and chloride. The efficiency of treatment was found to be directly proportional to the HRT. Therefore, treatment of effluents having a higher concentration of azo dyes can be optimized by decreasing the loading rate and increasing the HRT. Conversely, increasing the initial concentration of mixed azo dyes in the synthetic textile effluent negatively affected the removal of color, COD, and TDS. Comparing the performance of the anaerobic and sequential treatment, the sequential treatment was found to be a better method for treating textile effluents with lower concentrations $(100 \mathrm{mg} /$ $\mathrm{L})$ of mixed azo dyes. The higher concentration of mixed azo dyes $(500 \mathrm{mg} / \mathrm{L})$ was not efficiently treated in the sequential process as the COD removal was only $14 \%$, indicating that several pollutants were not effectively removed. The phytotoxicity analysis of the secondary sludge revealed that a high concentration of mixed azo dyes had been absorbed into the biomass, and this caused a reduction in the germination of Vigna unguiculata and also retarded the root and shoot length of the plant. The toxicity of the secondary sludge can be decreased by treatment in an anaerobic digester or by phytoremediation. The treated sludge can then be used as a biofertilizer. Therefore, it is possible to obtain complete treatment of textile effluents by combining biological methods, thus ensuring environmental protection and safety of the working personnel.

\section{Data Availability}

The data used in this study are available on request.

\section{Conflicts of Interest}

The authors declare that they have no conflicts of interest.

\section{Acknowledgments}

The authors acknowledge the University Grants Commission (UGC-SERO) (MRP-2017 (6970/16)) for funding this research. The authors would like to thank DST-FIST CRIST LAB, Stella Maris College (Autonomous), for providing the instrumentation facility. The authors would like to extend our gratitude to SAIF IITM, Department of Chemistry IITM, for GC-MS analysis.

\section{Supplementary Materials}

Figure S1 shows the K1 media used as a carrier material in MBBR before and after the formation of biofilm during the textile wastewater treatment. Figure S2 provides the operational cycle of the anaerobic sequential batch reactor in textile wastewater treatment. Figure S3 illustrates (a) decolorization of mixed azo dyes in the sequential anaerobicaerobic treatment process carried out in the An-SBR and aerobic MBBR and (b) biosorption of dyes into the biomass in the sequential anaerobic-aerobic treatment processes carried out in the An-SBR and aerobic MBBR. Figure S4 shows the removal of TKN in the complete anaerobic and the sequential anaerobic-aerobic textile effluent treatment process. Figure S5 presents the (a) FT-IR spectrum of $100 \mathrm{mg} / \mathrm{L}$ standard mixed azo dyes, (b) FT-IR spectrum of synthetic effluent with $100 \mathrm{mg} / \mathrm{L}$ mixed azo dyes treated in An-SBR, and (c) FT-IR spectrum of synthetic effluent with $500 \mathrm{mg} / \mathrm{L}$ mixed azo dyes treated in An-SBR. Figure S6 shows the elution profile of the untreated synthetic textile effluent. Figure S7 provides the GC-MS chromatogram of the untreated textile effluent. Figure S8 gives the (a) control plants grown in garden soil and (b) test plants grown in garden soil mixed with secondary sludge. Table S1 illustrates the phytotoxicity results on the root and shoot lengths of the control and test plants. (Supplementary Materials)

\section{References}

[1] A. N. Kulkarni, A. D. Watharkar, N. R. Rane, B.-H. Jeon, and S. P. Govindwar, "Decolorization and detoxification of dye mixture and textile effluent by lichen Dermatocarpon vellereceum in fixed bed upflow bioreactor with subsequent oxidative stress study," Ecotoxicology and Environmental Safety, vol. 148, pp. 17-25, 2018.

[2] A. D. Watharkar, S. K. Kadam, R. V. Khandare et al., "Asparagus densiflorus in a vertical subsurface flow phytoreactor for treatment of real textile effluent: a lab to land approach for in situ soil remediation," Ecotoxicology and Environmental Safety, vol. 161, pp. 70-77, 2018.

[3] D. Govindwar, "A review of the textile industries waste water treatment methodologies," International Journal Of Engineering Research, vol. 7, pp. 392-403, 2016.

[4] S. S. Salem, A. Mohamed, M. El-Gamal, T. Mohamed, and AmrFouda, "Biological decolorization and degradation of azo dyes from textile wastewater effluent by Aspergillus niger," Egyptian Journal of Chemistry, vol. 62, no. 10, pp. 1799-1813, 2019.

[5] I. Khouni, G. Louhichi, and A. Ghrabi, "Assessing the performances of an aerobic membrane bioreactor for textile wastewater treatment: influence of dye mass loading rate and biomass concentration," Process Safety and Environmental Protection, vol. 135, pp. 364-382, 2020.

[6] K. I. Đurđić, R. Ostafe, A. ĐurđevićĐelmaš et al., "Saturation mutagenesis to improve the degradation of azo dyes by versatile peroxidase and application in form of VP-coated yeast cell walls," Enzyme and Microbial Technology, vol. 136, p. 109509, 2020.

[7] S. Benkhaya, S. M'rabet, and E. Ahmed, "Classifications, properties, recent synthesis and applications of azo dyes," Heliyon, vol. 6, no. 1, Article ID e03271, 2020.

[8] P. Ramachandran, R. Sundharam, J. Palaniyappan, and A. P. Munusamy, "Potential process implicated in bioremediation of textile effluents: a review," Advances in Applied Science Research, vol. 4, no. 1, pp. 131-145, 2013.

[9] K. Meerbergen, K. A. Willems, R. Dewil, J. Van Impe, and L. Appels, "Isolation and screening of bacterial isolates from wastewater treatment plants to decolorize azo dyes," Journal of Bioscience and Bioengineering, vol. 125, no. 4, pp. 448-456, 2018.

[10] M. Lievens, S. Shakeel, and A. Rehman, "Microbial use for azo dye degradation-a strategy for dye bioremediation," International Microbiology, vol. 23, no. 2, pp. 149-159, 2020.

[11] A. Aretxaga, S. Romero, M. Sarra, and T. Vicent, "Adsorption step in the biological degradation of a textile dye," Biotechnology Progress, vol. 17, no. 4, pp. 664-668, 2001. 
[12] V. Khandegar and A. K. Saroha, "Electrocoagulation for the treatment of textile industry effluent-a review," Journal of Environmental Management, vol. 128, pp. 949-963, 2013.

[13] K. Sarayu and S. Sandhya, "Current technologies for biological treatment of textile wastewater-a review," Applied Biochemistry and Biotechnology, vol. 167, no. 3, pp. 645-661, 2012.

[14] B. E. L. Baêta, S. Q. Silva, D. R. S. Lima, and S. F. Aquino, "Influence of the Applied Organic Load (OLR) on Textile Wastewater Treatment Using Submerged anaerobic membrane bioreactors (SAMBR) in the presence of redox mediator and powdered activated carbon (PAC)," Brazilian Journal of Chemical Engineering, vol. 33, no. 4, pp. 817-825, 2016.

[15] R. M. Melgoza and A. G. Cruz, "Anaerobic/aerobic treatment of colorants present in textile effluents," Water Science and Technology, vol. 50, no. 2, pp. 149-155, 2004.

[16] M. M. Aldoury, W. M. ShAlabdraba, and M. B. Al-Bayati, "Performance of sequential anaerobic/aerobic biological treatment of synthetic wastewater containing two types of azo dye," Journal of SelÃßuk University Natural and Applied Science, pp. 234-248, 2014.

[17] N. C. Cinperi, E. Ozturk, and N. O. Yigit, "Treatment of woolen textile wastewater using membrane bioreactor, nanofiltration and reverse osmosis for reuse in production processes," Journal of Cleaner Production, vol. 223, pp. 837$848,2019$.

[18] J. Kitis, J. Johnson, and B. J. Lakshmi, "Bacterial community dynamics involved in Reactive Orange M2R dye degradation using a real time quantitative PCR and scale up studies using sequence batch reactor," Bioremediation Journal, vol. 22, no. 1-2, pp. 63-71, 2018.

[19] R. Pratiwi, S. Notodarmojo, and Q. Helmy, "Decolourization of remazol black-5 textile dyes using moving bed bio-film reactor," IOP Conference Series: Earth and Environmental Science, vol. 106, p. 012089, 2018.

[20] Buitrón, "American water works association, water pollution control federation, and water environment federation," Standard Methods For The Examination Of Water And Wastewater, Vol. 2, American Public Health Association, Washington, DC, USA, 1915.

[21] P. Banerjee, P. Das, and A. Mukhopadhyay, "Azo dye-rich wastewater treatment by combined biodegradation-adsorption approach: optimization, modeling and toxicity analysis," in Waste Water Recycling and Management, pp. 169-181, Springer, Berlin, Germany, 2019.

[22] M. Mathur, D. Gola, R. Panja, A. Malik, and S. Z. Ahammad, "Performance evaluation of two Aspergillus spp. for the decolourization of reactive dyes by bioaccumulation and biosorption," Environmental Science and Pollution Research, vol. 25, no. 1, pp. 345-352, 2018.

[23] M. Isik and D. T. Sponza, "Fate and toxicity of azo dye metabolites under batch long-term anaerobic incubations," Enzyme and Microbial Technology, vol. 40, no. 4, pp. 934-939, 2007.

[24] S.-A. Ong, E. Toorisaka, M. Hirata, and T. Hano, "Decolorization of azo dye (Orange II) in a sequential UASB-SBR system," Separation and Purification Technology, vol. 42, no. 3 , pp. 297-302, 2005.

[25] S. Şen and G. N. Demirer, "Anaerobic treatment of real textile wastewater with a fluidized bed reactor," Water Research, vol. 37, no. 8, pp. 1868-1878, 2003.

[26] J.-S. Chang, C. Chou, Y.-C. Lin, P.-J. Lin, J.-Y. Ho, and T. Lee $\mathrm{Hu}$, "Kinetic characteristics of bacterial azo-dye decolorization by Pseudomonas luteola," Water Research, vol. 35, no. 12, pp. 2841-2850, 2001.
[27] S. Q. Silva, D. C. Silva, M. C. S. Lanna, B. E. L. Baeta, and S. F. Aquino, "Microbial dynamics during azo dye degradation in a UASB reactor supplied with yeast extract," Brazilian Journal of Microbiology, vol. 45, no. 4, pp. 1153-1160, 2016.

[28] H. Mirbolooki, R. Amirnezhad, and A. R. Pendashteh, "Treatment of high saline textile wastewater by activated sludge microorganisms," Journal of Applied Research and Technology, vol. 15, no. 2, pp. 167-172, 2017.

[29] A. K. Yadav, S. Jena, B. C. Acharya, and B. K. Mishra, "Removal of azo dye in innovative constructed wetlands: influence of iron scrap and sulfate reducing bacterial enrichment," Ecological Engineering, vol. 49, pp. 53-58, 2012.

[30] C. Li, S. Tabassum, and Z. Zhang, "An advanced anaerobic expanded granular sludge bed (AnaEG) for the treatment of coal gasification wastewater," RSC Advances, vol. 4, no. 101, pp. 57580-57586, 2014.

[31] N. D. Lourenço, J. M. Novais, and H. M. Pinheiro, "Effect of some operational parameters on textile dye biodegradation in a sequential batch reactor," Journal of Biotechnology, vol. 89, no. 2-3, pp. 163-174, 2001.

[32] R. Maas and S. Chaudhari, "Adsorption and biological decolourization of azo dye Reactive Red 2 in semicontinuous anaerobic reactors," Process Biochemistry, vol. 40, no. 2, pp. 699-705, 2005.

[33] M. Punzi, F. Nilsson, A. Anbalagan et al., "Combined anaerobic-ozonation process for treatment of textile wastewater: removal of acute toxicity and mutagenicity," Journal of Hazardous Materials, vol. 292, pp. 52-60, 2015.

[34] G. Chen, J. Li, S. Tabassum, and Z. Zhang, "Anaerobic ammonium oxidation (ANAMMOX) sludge immobilized by waterborne polyurethane and its nitrogen removal performance-a lab scale study," RSC Advances, vol. 5, no. 32, pp. 25372-25381, 2015.

[35] F. D. Castro, J. P. Bassin, and M. Dezotti, "Treatment of a simulated textile wastewater containing the Reactive Orange 16 azo dye by a combination of ozonation and moving-bed biofilm reactor: evaluating the performance, toxicity, and oxidation by-products," Environmental Science and Pollution Research, vol. 24, no. 7, pp. 6307-6316, 2017.

[36] L. Bassin, D. Wei, H. H. Ngo, W. Guo, B. Du, and Q. Wei, "Application of anaerobic granular sludge for competitive biosorption of methylene blue and $\mathrm{Pb}(\mathrm{II})$ : fluorescence and response surface methodology," Bioresource Technology, vol. 194, pp. 297-304, 2015.

[37] M. Isık and D. T. Sponza, "Decolorization of azo dyes under batch anaerobic and sequential anaerobic/aerobic conditions," Journal of Environmental Science and Health, Part A, vol. 39, pp. 1107-1127, 2004.

[38] W. A. Al-Amrani, P.-E. Lim, C.-E. Seng, and W. S. Wan Ngah, "Factors affecting bio-decolorization of azo dyes and COD removal in anoxic-aerobic REACT operated sequencing batch reactor," Journal of the Taiwan Institute of Chemical Engineers, vol. 45, no. 2, pp. 609-616, 2014.

[39] A. A. Telke, S. M. Joshi, S. U. Jadhav, D. P. Tamboli, and S. P. Govindwar, "Decolorization and detoxification of Congo red and textile industry effluent by an isolated bacterium Pseudomonas sp. SU-EBT," Biodegradation, vol. 21, no. 2, pp. 283-296, 2010.

[40] N. Supaka, K. Juntongjin, S. Damronglerd, and P. Strehaiano, "Microbial decolorization of reactive azo dyes in a sequential anaerobic-aerobic system," Chemical Engineering Journal, vol. 99, no. 2, pp. 169-176, 2004.

[41] E. H. Koupaie, M. A. Moghaddam, and S. H. Hashemi, "Investigation of decolorization kinetics and biodegradation 
of azo dye Acid Red 18 using sequential process of anaerobic sequencing batch reactor/moving bed sequencing batch biofilm reactor," International Biodeterioratione Biodegradation, vol. 71, pp. 43-49, 2012.

[42] K. Balapure, K. Jain, N. Bhatt, and D. Madamwar, "Exploring bioremediation strategies to enhance the mineralization of textile industrial wastewater through sequential anaerobicmicroaerophilic process," International Biodeterioration \& Biodegradation, vol. 106, pp. 97-105, 2016.

[43] M. Jayapal, H. Jagadeesan, M. Shanmugam, and P. Danisha J, "anaerobic-aerobic treatment using plant microbe integrated system for degradation of azo dyes and their aromatic amines by-products," Journal of Hazardous Materials, vol. 354, pp. 231-243, 2018.

[44] P. Karpagam, R. Manikandan, and S. Selvakumar, "Decolorization and bioremediation of textile dye effluent by bioreactors containing novel bacterial consortium (KDDBO4, KDDBO5, KDDBO8 and KDDB11) and its effect on phytotoxicity," Research Journal of Chemistry and Environment, vol. 23, p. 3, 2019. 